https://nv.nltu.edu.ua

\title{
СПОСОБИ ОРГАНІЗАЦІЇ РУХУ МОНІТОРИНГОВИХ, ІНТЕРАКТИВНИХ І ДІАЛОГОВИХ ДАНИХ У СТРУКТУРАХ РОЗПОДІЛЕНИХ КОМП'ЮТЕРНИХ СИСТЕМ
}

Розроблено способи організації руху моніторингових, інтерактивних і діалогових даних у структурах розподілених кіберфізичних систем. Базовою ідеєю запропонованих способів є систематизація структур і класів джерел інформації в РКС, які формують моніторингові, інтерактивні та діалогові дані. Запропоновано метод розрахунку емерджентності класифікованих структур комп'ютеризованих систем управління (КСУ) таких типів: монопольної, автоматичного регулювання, моноканальної системи моніторингу, розділеного часу та мультипроцесорного опрацювання даних. Для кожної 3 названих структур оцінено критерії структурної складності та емерджентності. Запропоновано адитивно-мультиплікативний критерій, який враховує структурну складність окремих компонентів та архітектуру комп'ютерної системи. Запропоновано критерій емерджентності комп'ютерної системи у вигляді відношення кількості інформаційних зв'язків до загальної кількості компонентів системи. Застосування таких критеріїв дає змогу здійснити порівняння системних характеристик комп'ютерних і кіберфізичних систем, а також визначити перспективні напрями їх удосконалення. Викладено особливості функціональних можливостей різних архітектур КСУ та їхні недоліки в організації руху моніторингових, керувальних, діалогових й інформаційних поліфункціональних даних. Досліджено архітектуру мережевих станцій КСУ та оцінено їх емерджентність та структурну складність. Наведено структуру класичної трирівневої мережевої КСУ, яка оснащена на технологічному рівні контролерами низової мережі абонентськими станціями та спецпроцесорами, які інформаційно взаємодіють з інтелектуальними сенсорами, виконавчими механізмами та операторами об'єктів управління. Запропоновано на цеховому рівні застосовувати цехові процесори, які обслуговують оператори технологічних установок. На адміністративному рівні потрібно розміщувати адміністративні процесори, системний сервер, який має інформаційні зв'язки з адміністративною комп'ютерною мережею, базою даних, зовнішньою інформаційною системою та міжрівневим комутаційним процесором. Систематизовано інформаційні пари потоків даних, які формуються різними компонентами системи, що дає змогу вдосконалити інформаційні характеристики кожної пари компонентів КСУ з позиції сумісності та зменшення алгоритмічних перетворень моніторингових, керувальних, діалогових і поліфункціональних даних. З'ясовано, що відомі класифікації інформаційних потоків в КСУ не враховують різні типи інформаційних даних, які формуються ОУ-джерелом інформації. Запропоновано архітектуру системи ідентифікації семантичних, технологічних й інформаційних станів ОУ.

Ключові слова: розподілені комп'ютерні системи; типи даних; мережева станція; трирівнева мережева комп'ютерна система управління (КСУ); міжкомпонентні взаємодії; семантичний, технологічний, інформаційний стани джерела інформації.

\section{Вступ}

У теорії формування моніторингових, керувальних, діалогових структуризованих даних широко використовується цифрове опрацювання інформаційних потоків згідно із статистичним, кореляційним, спектральним, логіко-статистичним, кластерним, ентропійним та іншими системними підходами [8]. Водночас, практично, відсутня узагальнена інтегрована теорія формалізації аналітично заданих і поліфункціональних даних, які формуються джерелами інформації. Ця проблема особливо актуальна для визначення та застосування критеріїв інтелектуальної та структурної складності різних типів даних, що формуються в реальному масштабі часу різними класами джерел інформації.

Об'єкт дослідження - розподілені комп'ютерні сис- теми управління, які використовують у кіберфізичних системах.

Предмет дослідження - методи та засоби створення розподілених комп'ютерних систем управління, результати яких будуть використані для покращення системних взаємодій між компонентами кіберфізичних систем.

Мета роботи - розробити структури комп'ютеризованих систем управління та розрахувати їх інтелектуальність та структурну складність, використання яких буде забезпечувати можливість порівняння їх системних характеристик та здійснити їх удосконалення.

Для досягнення зазначеної мети визначено такі основні завдання дослідження: розробити спосіб організації руху моніторингових, інтерактивних і діалогових

Інформація про авторів:

Пітух Irop Романович, канд. техн. наук, доцент, кафедра спеціалізованих комп'ютерних систем. Email: pirom75@ukr.net; https://orcid.org/0000-0002-3329-4901

Возна Наталія Ярославівна, д-р техн. наук, доцент, кафедра спеціалізованих комп'ютерних систем. Email: nvozna@ukr.net; https://orcid.org/0000-0002-8856-1720

Цитування за ДСТУ: Пітух І. Р., Возна Н. Я. Способи організації руху моніторингових, інтерактивних і діалогових даних у структурах розподілених комп'ютерних систем. Науковий вісник НЛтУ України. 2021, т. 31, № 3. С. 101-108.

Citation APA: Pitukh, I. R., \& Vozna, N. Ya. (2021). Methods of organizing the movement of monitoring, interactive and dialog data in the structures of distributed computer systems. Scientific Bulletin of UNFU, 31(3), 101-108. https://doi.org/10.36930/40310316 
даних у структурах розподілених кіберфізичних систем; систематизувати структури та класи джерел інформації в РКС, які формують моніторингові, інтерактивні та діалогові дані; розробити метод розрахунку емерджентності класифікованих структур комп'ютеризованих систем управління таких типів: монопольної, автоматичного регулювання, моноканальної системи моніторингу, розділеного часу та мультипроцесорного опрацювання даних; дослідити структуру та розрахувати характеристики емерджентності та структурної складності трирівневої мережевої архітектури КСУ.

Наукова новизна отриманих результатів дослідження - вперше розроблено критерії оцінювання емерджентності та структурної складності архітектур і компонентів розподілених комп'ютерних систем управління, що дало змогу оптимізувати міжкомпонентні взаємодії у структурі такого класу систем.

Практична значущість результатів дослідження розроблено способи організації руху моніторингових, інтерактивних і діалогових даних, які дають змогу здійснити порівняння системних характеристик КСУ.

Аналіз останніх досліджень та публікацій. У наукових роботах $[5,7,11,13,17]$ описано теоретичні та методологічні положення побудови розподілених і кіберфізичних систем. Запропоновані критерії оцінювання структурної складності [15] та емерджентності [12] дають змогу провести оцінювання ефективності застосування кіберфізичних систем у різних галузях промисловості, визначити їх функціональні обмеження та оптимізації апаратної та часової складності. Milan Novak [6] дослідив мультипроцесорну систему для моніторингу лісів, відповідна розробка використовує БПЛА як компонент збирання даних на заповідних територіях. Компонентами такої системи $\epsilon$ : тепловізор, сенсор SWIR, сенсор NIR, мінікомп'ютер. Перевагами такої системи є організація міжкомпонентних інформаційних зв'язків. Наступна розробка системи SCADA [4] забезпечує максимальну універсальність іiі застосування в різних галузях промисловості. Проблемно орієнтована КСУ Centrum VP [2] забезпечує моніторинг та управління в реальному часі технологічними процесами. Особливістю тиражованих комп'ютерних систем реального часу $[1,3,14] \epsilon$ те, що вони недостатньо ефективно використовують спецпроцесори, які формують дані логіко-статистичних інформаційних моделей на їх низових технологічних рівнях, що значно знижує емерджентність таких систем. При цьому розширення типів та кількості застосованих спецпроцесорів на технологічному рівні КСУ дає змогу успішно вирішити проблему підвищення швидкодії формування та опрацювання даних у таких системах, розширити функціональні можливості, підвищити інтелект та їх надійність шляхом формування поліфункціональних даних у міжкомпонентних взаємодіях.

\section{Результати дослідження та їх обговорення}

Систематизація структур і класів джерел інформації в РКС, які формують моніторингові, інтерактивні та діалогові дані. Систематизацію структур і класів джерел інформації в РКС, які формують моніторингові, інтерактивні та діалогові дані, наведено в табл. 1. КСУ призначена для людино-машинного управління промисловими технологічними об'єктами у реальному масштабі часу. У таких системах автоматичне уп- равління виконується спеціалізованими комп'ютерними засобами, а людина-оператор виконує функції моніторингу станів ОУ, їх ідентифікацію у стані норми, не норми та аварії.

Спеціалізовані комп'ютерні засоби таких систем мають структуру джерел формування даних, поданих у п. 1 табл. 1. Такі джерела формують два двонаправлених потоки функціональних даних між парами: сенсори КСУ, ВМ - КСУ. При цьому ОУ, що є генераторами даних, класифікуються як прості (один технологічний параметр, один технологічний процес, один соціальний об'єкт), складні (одна технологічна установка, група операторів) та надскладні (цех, підприємство, організація).

У структурі системи автоматичного регулювання (див. п. 2 табл. 1) розрізняються такі класи даних: $X(t)-$ параметр задання, уставка; $\Delta X$ - різницева функція; $Z(X)$ - функція управління. У моноканальній структурі системи моніторингу оператори виконують функції моніторингу та керування параметрами ОУ (див. п. 3 табл. 1). У цій структурі використовують два типи двонаправлених потоків даних: ОУ-оператор, операторпроцесор, процесор-оператор. При цьому інформаційний потік даних ОУ-оператор реалізується шляхом опрацювання оптичних зображень.

Ця структура (див. п. 3 табл. 1) характеризується максимальним паралелізмом руху даних, внаслідок цього має максимальну надійність та живучість. Окрім цього, кожен оператор володіє всіма ресурсами процесорів, включаючи повний об'єм пам'яті, швидкодію, операційне та прикладне програмне забезпечення, час.

Основними недоліками такої архітектури є відсутність інформаційних зв'язків між процесорами, висока собівартість опрацювання даних, недостатнє використання часового ресурсу процесорів, вплив професійного рівня операторів на ефективність організації потоків руху. Архітектура розділеного часу характерна такими парами потоків даних (див. п. 4 табл. 1): оператор-комутатор (О-К), комутатор-потужний процесор (К-РР). Така організація потоків даних не забезпечує високопаралельного режиму обміну, що зумовлено наявністю комутатора.

При цьому також виникають ефекти старіння інформації, а також висока ймовірність утворення черг. Позитивними характеристиками такої організації руху ПФД $€$ зниження собівартості опрацювання даних за рахунок більш ефективного завантаження КС в часі та колективного користування ПЗ і масивами даних.

Основними недоліками цієї організації руху ПФД є істотне зниження надійності, яке зумовлене наявністю комутатора та одного колективного процесора, а також обмеження ресурсів часу для опрацювання даних кожного оператора. Структура мультипроцесорного опрацювання даних (див. П. 5 табл. 1) забезпечує істотне підвищення надійності системи, можливості розпаралелення інформаційних потоків та істотне зниження собівартості опрацювання даних за рахунок одночасного використання супервізора та групи процесорів різної потужності.

При цьому супервізор не тільки аналізує активність та характер задач, які виконуються операторами, але й розподіл потужностей процесорів та їх головних ресурсів. Незалежність від активності сенсорних даних забезпечується цілодобовим рішенням фонових задач, які завантажуються в супервізор операторами через комута- 
тор. Позитивною характеристикою такої організації руху даних $€$ наявність прямих інформаційних зв'язків між процесорами на підставі високошвидкісної паралельної шини.

Табл. 1. Структури та структурна складність джерел інформації в РКС

\begin{tabular}{|c|c|c|}
\hline № 3/ח & Назва та $k_{c}$ структури & Структурне відображення системи \\
\hline 1 & $\begin{array}{c}\text { Структура комп'ютеризованої } \\
\text { системи управління } \\
k_{c}=148,4\end{array}$ & ОУ - об'єкт управління, S, ВМ - інтелектуальні сенсори та виконавчі механізми, КСУ - \\
\hline 2 & $\begin{array}{c}\text { Структура системи автома- } \\
\text { тичного регулювання } \\
k_{c}=246\end{array}$ & $\begin{array}{l}\text { - схема порівняння; КСР - контролер системи регулювання; ОУ - об'єкт управління; } \\
S \text { - сенсор; } f_{y} \text { - вхідна функція; } \mathrm{f}_{\mathrm{z}} \text { - функція зовнішніх впливів; } Y(t) \text { - вихідна функція }\end{array}$ \\
\hline 3 & $\begin{array}{c}\text { Структура моноканальної } \\
\text { системи моніторингу } \\
k_{c}=104\end{array}$ & $\underset{\mathrm{O}-\text { оператор, } \mathrm{P} \text { - процесор }}{\longrightarrow}$ \\
\hline 4 & $\begin{array}{c}\text { Структура КСУ розділеного } \\
\text { часу } k_{c}=119\end{array}$ & К - комутатор, РP - потужний процесор \\
\hline 5 & \begin{tabular}{|c|} 
Структура мультипроцесор- \\
ного опрацювання даних \\
$k_{c}=262$
\end{tabular} & 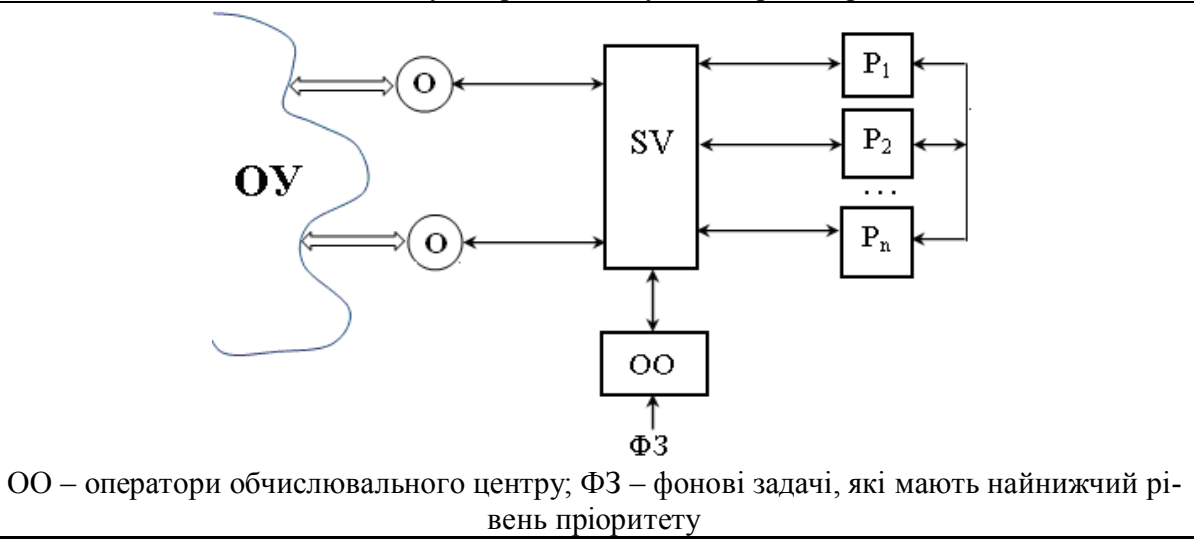 \\
\hline
\end{tabular}

Описані системи формування та обміну ПФД класу належать до класу комп'ютеризованих систем управління.

Мережеві архітектури КСУ організовуються на підставі реалізації функцій формування, цифрового опрацювання, зберігання, управління об'єктами та передавання інформації мережевими станціями (СТ) з базовою архітектурою (рис. 2), де формують такі інформаційні потоки між парами об'єктів, які характеризуються різною структурною складністю, проблемною орієнтацією, об'ємом та швидкістю обміну даними: ОУ-О, О-
АП, АП-P, Р-MM, MM-КM, S-КНM, КНM-ВM, КНM-P, KНM-КМ.

Компоненти мережевої станції виконують такі функції: збір та аналіз технологічних і техніко-економічних даних (ТЕД) у реальному масштабі часу виконують оператори, оснащені спеціалізованими абонентськими пунктами у вигляді промислових комп'ютерів, спеціалізованих пультів, табло, панелей перемикачів та ін.

Базовий процесор станції Р виконує функції оперативної архівації даних на заданому інтервалі часу, по- 
будові інформаційних моделей ОУ згідно з характеристичним функціоналом $X_{O y}$, контролем відхилень станів ОУ від норми та організації мережевого зв'язку через модем 3 іншими станціями та серверами КСУ.

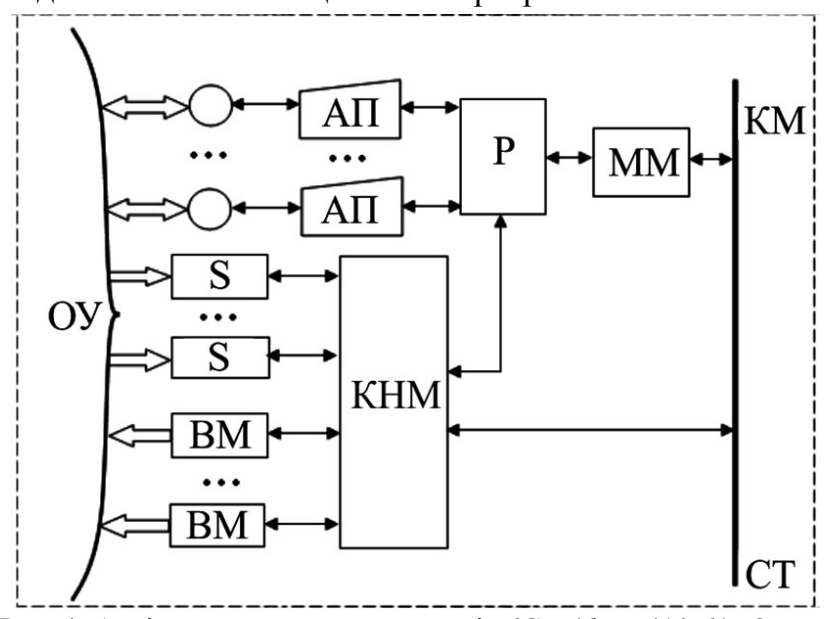

Рис. 1. Архітектура мережевої станції КСУ $\left(k_{c}=410,6\right)$ : ОУ об'єкт управління; О - оператор; АП - абонентський пункт; $\mathrm{P}$ - процесор; MM - модем; KM - комп'ютерна мережа; S сенсор; КНМ - контролер низової мережі; ВМ - виконавчий механізм

Характеристика емерджентності системи визначає ступінь складності, архітектурної досконалості та ії інтелекту. Емерджентність оцінюють за такою формулою [9]:

$$
K_{e}=\frac{N_{3}}{N_{e}},
$$

де: $N_{3}-$ кількість інформаційних зв'язків; $N_{e}-$ кількість елементів або компонентів системи. За означенням Дж. Мартіна, систему вважають емерджентною, тобто такою, що має високі інформаційно-інтелектуальні властивості, за умови, коли $K_{e} \geq 2$ [5].

Синтез та аналіз структур і компонентів РКС потребує чіткого визначення системи критеріїв, на підставі яких здійснюється порівняння та оптимізація характеристик і способів організації руху даних у КС. Одним з важливих критеріїв оцінювання досконалості архітектури РКС є критерій структурної складності, який визначають у вигляді зваженої суми структурних характеристик компонентів 3 урахуванням їх інформативності та вагових оцінок:

$$
k_{c}=\sum_{i=1}^{n} \alpha_{i} P_{i},
$$

де: $P_{i} \in(l, P, x, d, r, h, z, b, c, i, n, a, f)-$ інформативні параметри атрибутів структур; $\alpha_{i}-$ вагові коефіцієнти експертних оцінок структурної складності елементів і компонентів структур.

Цей критерій дає змогу оцінити та оптимізувати системні характеристики діючих і проектованих архітектур моніторингових, інтерактивних i діалогових КСУ.

Однак критерій оцінювання структурної складності не враховує характеристики інформативності компонентів структури, тому автор [16] запропонував критерій ефективності структури шляхом розрахунку відношення між інформаційною та структурною складністю згідно з виразом:

$$
k_{e}=K \cdot \frac{F_{C}}{k_{c}}=K \cdot \sum_{j=1}^{m} f_{j} / \sum_{i=1}^{n} \alpha_{i} P_{i} \Rightarrow \max ,
$$

де: $K$ - ідентифікатор рівня ПФД ( $K=n, \ldots-$ відповідно для $n$-рівневих структур); $F_{C}-$ інформаційна складність пристрою; $f_{j}-$ функціонально-інформаційна характеристика структури.

Результати опрацювання параметрів технологічного процесу у вигляді функціоналу структуризованих даних $X_{O y}$, який формується на виході процесора Р у вигляді образно-кластерної моделі моніторингових станів ОУ, описує набір аналітичних функцій, згідно з якими виконують опрацювання даних сенсорів, розрахунок функцій та математичних сподівань, кореляцій та ін., які використовують для моніторингу стану ОУ та контролю його відхилень від норми.

Для магістральної організації руху даних характерне зниження собівартості опрацювання розподілених даних за рахунок істотного зниження вартості магістрального фізичного каналу зв'язку на підставі провідних ліній (витої пари та коаксіального кабеля) або волоконнооптичних ліній.

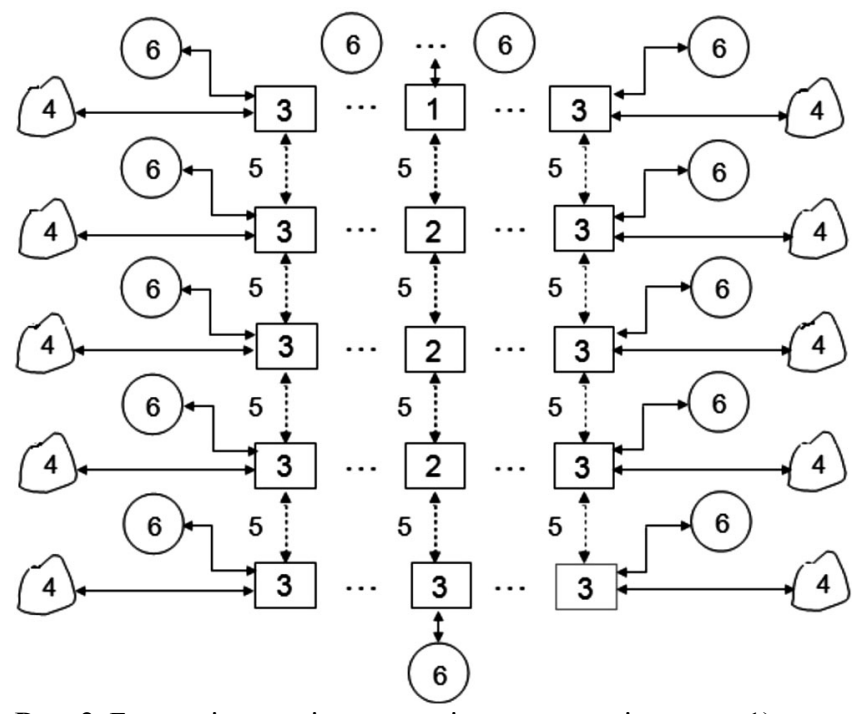

Рис. 2. Багаторівнева зірково-магістральна архітектура: 1) системний сервер; 2) станції магістрально-зіркової структури; 3) станції бісигнального оптичного зв'язку кільцевої естафетної архітектури; 4) об'єкти моніторингу та управління; 5) інформаційні зв'язки; 6) оператори

Головними перевагами такої структури є можливість встановлення безпосередніх інформаційних зв'язків між станціями, а також колективне використання ресурсів сенсорних даних і сервера. Водночас, ця структура має низку істотних недоліків, зумовлених можливістю колізій та конфліктів, які ліквідуються на підставі спеціальних складних протоколів доступу, а також низьку надійність, зумовлену одним каналом зв'язку.

Серед архітектур, на підставі фізичних ліній зв'язку, найефективнішою $є$ багаторівнева зірково-магістральна, яка забезпечує максимальне розпаралелення інформаційних потоків і може бути ефективно застосована у структурах моніторингових, інтерактивних і діалогових систем. Для усунення недоліків магістральної архітектури та зірково-магістральної архітектури з фізичними лініями зв'язку запропонована кільцево-зіркова архітектура на підставі оптичних безпровідних ліній зв'язку. Ця архітектура відповідає умовам ії застосування для побудови IРКС і діалогових систем в умовах фонового моніторингу природоохоронних об'єктів. Структуру такої системи зображено на рис. 2 [10]. 


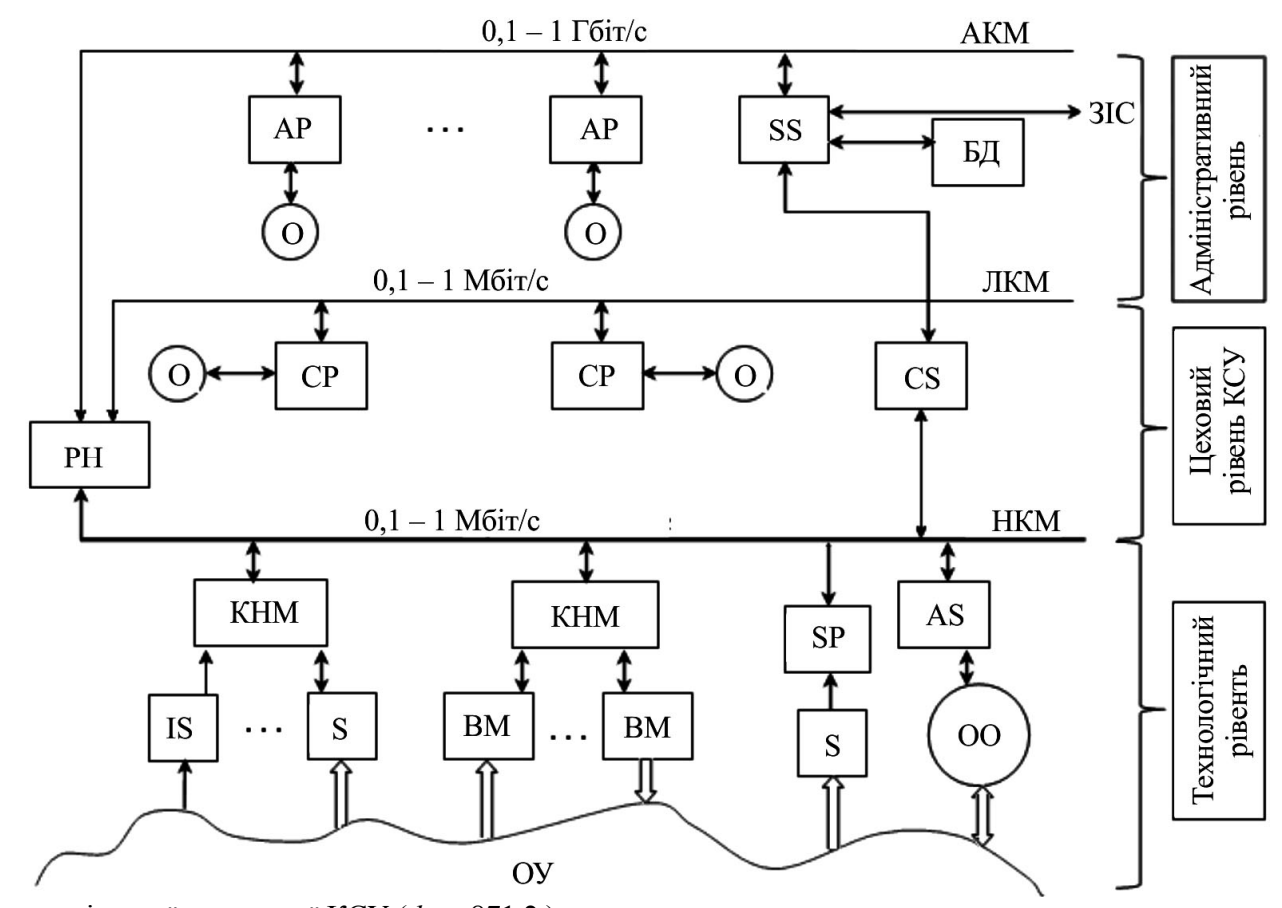

Рис. 3. Структура трирівневої мережевої КСУ $\left(k_{c}=871,2\right)$

Структура та функцї трирівневої мережевої $\boldsymbol{K} \boldsymbol{C У}$. Усі три класи системи управління синтезовані та структурно об'єднані на виробництві у вигляді трирівневої мережевої КСУ (рис. 3). Складові компоненти трирівневої КСУ:

- ОУ - складний об'єкт управління, що є комплексом взаємопов'язаних інформаційно та матеріально технологічних установок $з$ випуску конкретної продукції, який обслуговується інформаційною вимірювальною системою, системами автоматичного регулювання та операторами трьох рівнів (технологічного, цехового та адміністративного), які оснащені автономними процесорами програмного опрацювання даних;

- $\mathrm{S}$ - сенсори виконують функції вимірювання фізичних значень технологічних параметрів та перетворення у стандартні електричні сигнали;

- IS - інтелектуальний сенсор;

- ВМ - виконавчі механізми - пристрої управління, оснащені інтерфейсними засобами дистанційного зв'язку, які виконують фізичне регулювання технологічними параметрами;

- SP - спецпроцесори, які виконують функції побудови моделей ОУ на підставі статистичного, кореляційного, спектрального, логіко-статистичного, кластерного та ентропійного опрацювання сигналів;

- ОО - група операторів, які виконують функції моніторингу та управління об'єктом у ручному режимі;

- $\mathrm{AS}$ - абонентська станція оператора, оснащена промисловим комп'ютером та модемом для телекомунікаційного зв'язку з низовою комп'ютерною мережею (НКМ);

- КНМ - контролери низової мережі, якій виконують функції аналого-цифрового перетворення сигналів сенсорів, цифрове опрацювання даних, їх кодування та забезпечення інтерфейсного зв'язку з верхніми рівнями системи;

- РН - процесор-шлюз виконує функції комутації пакетів даних між різними рівнями мережі та узгодження швидкості їх передавання;

- НКМ - низова комп'ютерна мережа виконує функції інтерфейсного зв'язку між різними КНМ та РН-процесором;

- СР - цеховий процесор - персональні комп'ютери, якими оснащені оператори цехів, що виконують операції збирання інформаційних даних і здійснюють їх опрацювання згідно 3 моделлю ОУ;

- О - оператори виконують функції моніторингу станів окремих технологічних установок або окремих груп параметрів (витрата електроенергії, газу, води тощо);
- $\mathrm{CS}$ - комутаційний сервер призначений для організації рівневого інформаційного зв'язку між технологічним та адміністративним рівнями системи;

- ЛКМ - локальна комп'ютерна мережа виконує функції інтерфейсного зв'язку між процесорами та операторами цехового рівня, має швидкодію на порядок вищу відносно швидкодії НКМ;

- АР - адміністративний процесор є ПК, яким оснащені оператори адміністративної системи (головні інженер, метролог, енергетик, технолог та оператори бухгалтерської підсистеми);

- SS - системний сервер виконує функції організації інтефейсних зв'язків всіх трьох рівнів, а також зв'язку з вищими рівнями управління;

- БД - база даних;

- АКМ - адміністративна комп'ютерна мережа, яка має високу швидкодію і захищена від зовнішнього впливу;

- ЗІС - зовнішне інформаційне середовище (інтернет та інформаційне хмарне середовище);

- ККМ - корпоративна комп'ютерна мережа.

У цій структурі джерелами інформації формують такі пари потоків даних: сенсор-КНМ,

КНМ-виконавчий механізм, ОУ-опертор, KHM-HKM, AS -HKM

$$
\begin{array}{cc}
\text { НКМ-РН, } & \text { Оператор-СР } \\
\text { РН-ЛКМ, } & \text { АР-ККМ } \\
\text { ЛКМ-СП } & \text { ККМ- SS } \\
\text { СР-ЛКМ } & \text { SS -ККМ } \\
\text { СР-оператор } & \text { SS-3IC }
\end{array}
$$

Розроблення та реалізація теорії структуризації даних, $з$ урахуванням їх поліфункціональних характеристик та проблемної орієнтації, дає змогу оптимізувати процеси перетворень інформаційних потоків та спростити алгоритми обчислень і реалізацію програмно-апаратних засобів під час організації руху інформаційних потоків у РКС. Практичне застосування цієї теорії також дає змогу істотно підвищити функціональні можливості оцінювання впливу рівня структуризації даних на процеси збирання, опрацювання, передавання, зберігання, відображення даних i керування складними об'єктами, що відповідно знижує вартість комп'ютерних систем, собівартість організації руху даних, підвищує рівень достовірності ідентифікації станів ОУ, а загалом підвищує рівень надійності та безпеки функціонування розподілених комп'ютерних систем. 
Оператор технологічної установки (О) виконує функції еврістичної ідентифікації семантичних і екологічних станів ОУ, які інваріантні різним технологічним та інформаційним станам ОУ, і не можуть бути однозначно визначені різними логічними аналізаторами $S_{i}, X_{j}, I_{k}$ автономно.

Інформаційна система контролю та ідентифікації станів ОУ дає змогу зменшити надлишковість даних на етапі первинного обробляння. Обсяг даних, що формується усіма сенсорами, на порядок перевищує обсяг вихідних даних промислового контролера, що через НКМ надходять до комп'ютера-сервера. Скорочення обсягів даних досягається за рахунок кодування стану ОУ та формалізованого параметра, що описує цей стан. Якщо об'єкт контролю має 15 сенсорів, кожний 3 яких формує 10-розрядне значення і може перебувати в одному $з$ восьми станів, то застосування запропонованої системи дає змогу скоротити обсяг даних зі 150 біт до 13 біт, а в окремих випадках до 3 біт.

Інформаційна система контролю та ідентифікації станів ОУ повинна бути обладнана відповідними засобами автоматики і включати: сенсори $\left(C_{p}\right)$; логічні та еврістичні аналізатори семантичних $\left(S_{i}\right)$, технологічних $\left(X_{j}\right)$ та інформаційних $\left(I_{k}\right)$ станів ОУ; промислові контролери (ПрК), низову комп'ютерну мережу (НКМ) та базовий комп'ютер-сервер диспетчерського центру (рис. 4). Структура модуля оцінки стану об'єкта управління характеризує інформативність та структурну складність на підставі даних табл. 1 [16].

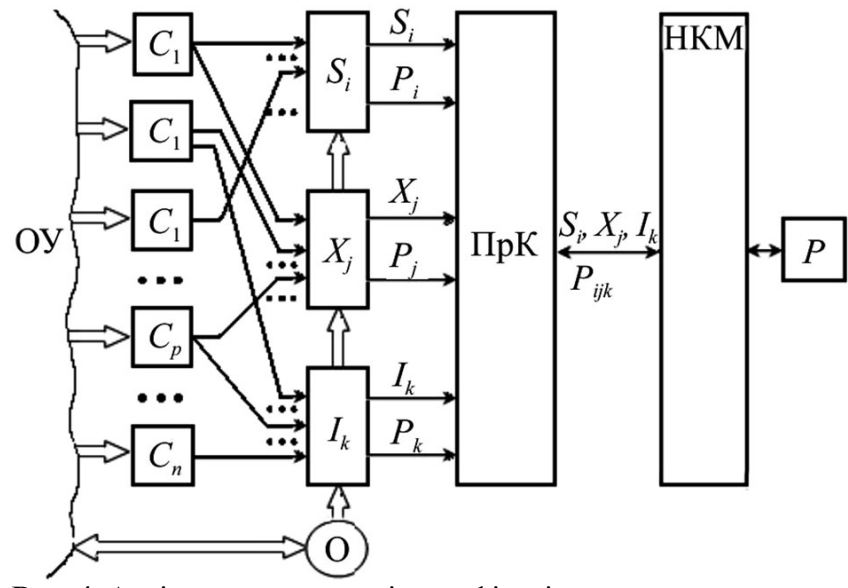

Рис. 4. Архітектура системи ідентифікації семантичних, технологічних і інформаційних станів ОУ: О - оператор технологічної установки; $P_{i}, P_{j}, P_{k}$ - формалізовані параметри семантичних, технологічних та інформаційних станів ОУ; $P_{i j k}$ - характеристичний параметр технологічного стану ОУ

Табл. 2. Експертні оцінки інформативності та структурної складності компонентів системи ідентифікації станів

\begin{tabular}{|c|c|c|c|}
\hline \multirow[b]{2}{*}{ Назва об'єкта } & \multicolumn{2}{|c|}{ Складність: } & \multirow{2}{*}{$\begin{array}{l}\text { Кількість } \\
\text { об'єктів, } \\
\text { шт }\end{array}$} \\
\hline & $\begin{array}{l}\text { інформа- } \\
\text { ційна }\end{array}$ & $\begin{array}{c}\text { структур- } \\
\text { на }\end{array}$ & \\
\hline Сенсори (C) & 100 & 27 & $n$ \\
\hline $\begin{array}{l}\text { Аналізатори логічних, ев- } \\
\text { рістичних і технологічних } \\
\text { станів }\left(S_{i}, X_{j}, I_{k}\right)\end{array}$ & 15 & 35 & 3 \\
\hline $\begin{array}{l}\text { Промисловий контролер } \\
\text { (ПрК, КНМ) }\end{array}$ & 30 & 47 & 1 \\
\hline $\begin{array}{l}\text { Низова комп'ютерна мере- } \\
\text { жа (НКМ) }\end{array}$ & 5 & 31 & 1 \\
\hline Процесор (Р) & 40 & 21 & 1 \\
\hline Оператор (O) & 15 & 13,2 & 1 \\
\hline
\end{tabular}

Відповідно до даних табл. 2 та згідно 3 критерієм (3), оцінка інформативності становить $F_{C}=100 n+135$ одиниць, структурної складності $k_{c}=27 n+217,2$ одиниць, а ефективність структури $k_{e}=\frac{100 n+135}{27 n+217}$ одиниць.

Отримана інформація про ОК та про сигнали, що його описують, подається у формах:

- доступних безпосередньо вимірюванню входів, виходів, змінних стану;

- моделей ОУ, ДІ або сигналів;

- оцінок сигналів та станів.

Властивості кожного $з$ наведених вище класів ОУ можуть бути описані у вигляді сигнальної, статистичної та ентропійної моделей.

Інформація про ОУ надається у НКМ у цифровому вигляді. Тому у названих моделях доцільно дослідити системні властивості різних класів дискретних ОУ, відповідно властивості аналогових ОУ можуть бути описані в класі дискретних ОУ з певною заданою точністю.

Визначення інформаційних станів ОУ грунтується на теорії і технології кодування дискретних ОУ. При цьому найбільш актуальним завданням $є$ кодування квазістаціонарних ОУ, до яких відносять широкий клас промислових об'єктів.

Виконана систематизація та дослідження архітектур у попередньому розділі дали змогу встановити пари активних вузлів у структурі РКС, де реалізується формування та обмін різними типами функціонально орієнтованих даних. Класифікацію таких типів даних наведено в табл. 3. На сьогодні існує велика кількість тиражованих РКС, які реалізують досліджені архітектури та їх компоненти.

Проведені дослідження дають змогу встановити такі типи поліфункціональних даних, які використовують для обміну інформаційними потоками між компонентами РКС: інформаційно-вимірювальні аналого-сигнальні та цифрові біт та байт орієнтовані дані (IBM), цифрові байт орієнтовані потоки даних (ЦПД), мережно-інтерфейсні сигнально-маніпульовані біт орієнтовані дані (МІД, СМД), які передаються по фізичних, безпровідних і оптичних лініях зв'язку електричними, електромагнітними та оптичними сигналами.

Обговорення результатів дослідження. Під час аналізу отриманих результатів дослідження, порівнявши їх, можна прийти до висновку, що для розв'язання різних поставлених задач перед розподіленою комп'ютерною системою управління доцільно використовувати запропоновані критерії розрахунку емерджентності та структурної складності компонентів та архітектур даного класу систем. Для організації руху моніторингових, керувальних, діалогових і поліфункціональних даних найоптимальнішим $\epsilon$ використання спецпроцесорів формування логіко-статистичних інформаційних моделей. Цей вибір забезпечує розширення функціональних можливостей та покращує міжкомпонентну взаємодію інформаційних потоків в архітектурі комп'ютерних систем. Під час розв'язання поставлених задач $є$ неактуальним підвищення універсальності та апаратної складності мікроконтролерів низової мережі КСУ, що в багатьох випадках є функціонально надлишковим та знижує характеристики мобільності та надійності таких компонентів. 
Табл. 3. Типи пар компонентів РКС, між якими виконують обмін даними

\begin{tabular}{|c|c|c|c|c|c|}
\hline $\begin{array}{l}\text { № } \\
\text { 3/ח } \\
\end{array}$ & Пов'язані компоненти & Тип даних & Біт орієнтовані дані & $\begin{array}{c}\text { Байт орієнтовані } \\
\text { дані } \\
\end{array}$ & \begin{tabular}{|c} 
Структура організації \\
руху даних на рис. \\
\end{tabular} \\
\hline 1 & $\mathrm{~S}-\mathrm{KСУ}$ & $\begin{array}{c}\text { Інформаційно-вимірюваль- } \\
\text { ні дані (ІВД) }\end{array}$ & + & + & п. 1 табл. 1 \\
\hline 2 & КСУ $\leftrightarrow \mathrm{BM}$ & $\begin{array}{l}\text { Цифрові потоки даних } \\
\text { (ЦПД) }\end{array}$ & + & + & п. 1 табл. 1 \\
\hline 3 & $X(t)-$ & ІВД & & + & п. 2 табл. 1 \\
\hline 4 & $\bigotimes_{-\kappa C Р}$ & ІВД & & + & п. 2 табл. 1 \\
\hline 5 & $\mathrm{KCP}-\mathrm{BM}$ & IВД & & + & п.2 табл. 1 \\
\hline 6 & $s-\varnothing$ & ІВД & & + & п.2 табл. 1 \\
\hline 7 & $\mathrm{O} \leftrightarrow \mathrm{P}$ & ЦПД & & + & п. 2 табл. 1 \\
\hline 8 & $\mathrm{O} \leftrightarrow \mathrm{AP}$ & ЦПД & & + & 2 \\
\hline 9 & $\mathrm{AP} \leftrightarrow \mathrm{AKM}$ & $\begin{array}{c}\text { Мережно-структуризовані } \\
\text { дані (МСД) }\end{array}$ & + & & 2 \\
\hline 10 & $\mathrm{SS} \rightarrow$ БД & ЦПД & & + & 2 \\
\hline 11 & $\mathrm{SS} \leftrightarrow \mathrm{AKM}$ & МСД & + & & 2 \\
\hline 12 & $\mathrm{SS} \leftrightarrow 3 \mathrm{IC}$ & МСД & + & & 2 \\
\hline 13 & $\mathrm{O} \leftrightarrow \mathrm{CP}$ & ЦПД & & + & 2 \\
\hline 14 & $\mathrm{SS} \leftrightarrow \mathrm{CS}$ & МСД & + & & 2 \\
\hline 15 & $\mathrm{AKM} \leftrightarrow \mathrm{PH}$ & МСД & + & & 2 \\
\hline 16 & ЛКМ $\leftrightarrow$ PH & МСД & + & & 2 \\
\hline 17 & $\mathrm{CP} \leftrightarrow$ ЛКМ & МСД & + & & 2 \\
\hline 18 & $\mathrm{CP} \leftrightarrow \mathrm{PH}$ & ЦПД & + & & 2 \\
\hline 19 & $\mathrm{PH} \leftrightarrow \mathrm{HKM}$ & МСД & + & & 2 \\
\hline 20 & $\mathrm{CS} \leftrightarrow \mathrm{HKM}$ & МСД & + & & 2 \\
\hline 21 & КНM $\leftrightarrow$ HКM & МСД & + & & 2 \\
\hline 22 & $\mathrm{SP} \leftrightarrow \mathrm{HKM}$ & МСД & + & & 2 \\
\hline 23 & $\mathrm{AS} \leftrightarrow \mathrm{HKM}$ & МСД & + & & 2 \\
\hline 24 & $\mathrm{~S} \rightarrow \mathrm{KHM}$ & IBM & + & + & 2 \\
\hline 25 & IS ↔ KHM & IBM, ЦПД & + & + & 2 \\
\hline 26 & $\mathrm{BM} \leftrightarrow \mathrm{KHM}$ & ЦПД & + & + & 2 \\
\hline 27 & $\mathrm{~S} \rightarrow \mathrm{SP}$ & IBM & + & + & 2 \\
\hline 28 & $\mathrm{OO} \leftrightarrow \mathrm{AS}$ & ЦПД & & + & 2 \\
\hline
\end{tabular}

Отже, проаналізовано результати застосування різних архітектур КСУ для розв'язання поставлених задач, визначено емерджентність та структурну складність для кожної окремої архітектури.

\section{Висновки}

У цій роботі запропоновано критерії розрахунку емерджентності та структурної складності різних типів структур КСУ: монопольної, автоматичного регулювання, моноканальної системи моніторингу, розділеного часу та мультипроцесорного опрацювання даних. Запропоновано також адитивно-мультиплікативний критерій, який враховує структурну складність окремих компонентів та архітектуру комп'ютерної системи. Дослідження показали, що застосування запропонованих критеріїв дає змогу здійснити порівняння системних характеристик розподілених комп'ютерних та кіберфізичних систем, а також визначити перспективні напрями їх удосконалення.

Викладено функціональні особливості різних архітектур КСУ та їх недоліки в організації руху моніторингових, керувальних, діалогових й інформаційних поліфункціональних даних.

На підставі наведеної структури класичної трирівневої мережевої КСУ обгрунтовано застосування цехових, адміністративних і системних процесорів на відповідних рівнях КСУ для забезпечення інтерактивної взаємодії всіх учасників системи управління.
Систематизовано пари інформаційних потоків даних, які формуються різними компонентами системи, що дає змогу вдосконалити інформаційні характеристики кожної пари компонентів КСУ з позиції сумісності та зменшення алгоритмічних перетворень даних.

\section{References}

1. Advancing the future of energy. (2021). Ofitsiinyi sait kompanii General Electric Company, 236 p. Retrieved from; https://www.ge.com/. [In Ukrainian].

2. Centum, V. P. (2021). Systema upravlinnia vyrobnytstvom Centum V. P. Retrieved from: https://www.yokogawa.com/solutions/products-platforms/control-system/distributed-controlsystems-dcs/centum-vp/. [In Ukrainian].

3. Elektrosvit. (2021). Ofitsiinyi sait firmy "Elektrosvit". Retrieved from; https://www.es.ua. [In Ukrainian].

4. Helpiks.org. (2021). Osoblyvosti SCADA v protsesi upravlinnia. Retrieved from; https://helpiks.org/8-78205.html. [In Ukrainian].

5. Melnyk, A. (2015). Cyber-physical systems: the problems of creation and direcsion of development. Computer System and Networks, Lviv Polytechic National University Publishing, 692, 100107.

6. Novák, Milan, Prokýšek, Miloš, Doležal Petr et. al. (2020). Multisensor UAV system for the forest monitoring. Proceeding of the 10th International Conference "Advanced Computer Information Technologies", ACIT2020, 293-296.

7. Nykolaichuk, Ya. M. (2012). Kody polia Halua: teoriia ta zastosuvannia. Monohrafiia. Ternopil: TzOV "Terno-hraf", 576 p. [In Ukrainian].

8. Nykolaichuk, Ya. M. (2017). Spetsializovani kompiuterni tekhnolohii v informatytsi. Monohrafiia. Ternopil: "Beskydy", 919 p. [In Ukrainian]. 
9. Nykolaichuk, Ya. M., Vozna, N. Ya., \& Pitukh, I. R. (2013). Structuring the movement of data in computer systems. Ternopil: Terno-graf, $284 \mathrm{p}$.

10. Nykolaychuk, Yaroslav, Petrashchuk, Yaroslav, Slobodian, Olena et al. (2020). Structure and Functioning of Information Systems of Background Monitoring of Landscape Elements of Gorgany Nature Reserve. Proceeding of the 10th International Conference "Advanced Computer Information Technologies". ACIT2020, 317-322.

11. Palahin, O. V., \& Kaliavin, V. P. (2006). Arkhitekturno-ontolohichni pryntsypy rozbudovy intelektualnykh informatsiinykh system. Matematychni mashyny i systemy, 1(4), 15-20. [In Ukrainian].

12. Pitukh, I. R. (2015). Rozshyrennia kryteriiv interaktyvnosti kompiuteryzovanykh system. Mizhnarodnyi naukovo-tekhnichnyi zhurnal "Optyko-elektronni informatsiino-enerhetychni tekhnolohii", 29, 30-34. [In Ukrainian].
13. Pomorova, O. V. (2007). Teoretychni osnovy, metody ta zasoby intelektualnoho diahnostuvannia kompiuternykh system. Monohrafiia. Khmelnytskyi: Triada-M, 252 p. [In Ukrainian].

14. Schneider Electric. (2021). Ofitsiinyi sait firmy Shneider Elektryk Ukraina. Retrieved from; https://www.schneider-electric.ua. [In Ukrainian].

15. Vozna, N. Ya. (2015). Osnovy teorii strukturyzatsii polifunktsionalnykh elementiv skladnykh system. Visnyk Khmelnytskoho natsionalnoho universytetu, 2(223), 204-208. [In Ukrainian].

16. Vozna, N. Ya. (2018). Strukturyzatsiia polifunktsionalnykh danykh: teoriia, metody ta zasoby. Monohrafiia. Ternopil: TNEU, 378 p. [In Ukrainian].

17. Zamikhovskyi, L. M., \& Kaliavin, V. P. (2004). Osnovy teorii nadiinosti $i$ diahnostyky tekhnichnykh system: navch. posibn. Polumia, 360 p. [In Ukrainian].

\section{METHODS OF ORGANIZING THE MOVEMENT OF MONITORING, INTERACTIVE AND DIALOG DATA IN THE STRUCTURES OF DISTRIBUTED COMPUTER SYSTEMS}

Methods for organizing the movement of monitoring, interactive and dialog data in the structures of distributed cyberphysical systems have been developed. The basic idea of the proposed methods is the systematization of structures and classes of information sources in distributed computer systems that generate monitoring, interactive and dialog data. A method for calculating the emergence of classified structures of computerized control systems of the following types: monopoly, automatic control, mono-channel monitoring system, split time and multiprocessor data processing. For each of these structures, estimates of the criteria of structural complexity and emergence are calculated. An additive-multiplicative criterion of structural complexity is proposed, which takes into account the structural complexity of individual components and the architecture of the computer system. The criterion of emergence of a computer system in the form of the ratio of the number of information links to the total number of system components is proposed. The application of such criteria allows comparing the system characteristics of computer and cyberphysical systems, as well as identifying promising areas for improvement. The peculiarities of the functional capabilities of different architectures and their shortcomings in the organization of the movement of monitoring, control, dialog and information fields of functional data are presented. The architecture of network stations is studied; estimates of their emergence and structural complexity are given. The structure of the classic three-level networked computerized control system is presented, which is equipped at the technological level with low-level network controllers, subscriber stations and special processors that interact with intelligent sensors, actuators and operators of control objects. At the shop level, shop processors are used, which are serviced by operators of technological installations. At the administrative level, there are administrative processors, a system server that has information connections with the administrative computer network, database, external information system, and inter-level switching processor. Systematized information pairs of data streams formed by different components of the system, which allows improving the information characteristics of each pair of components of the computerized control system from the standpoint of compatibility and reduce algorithmic transformations of monitoring, control, dialog and multifunctional data. Known classifications of information flows do not take into account the different types of information data that are formed by the object of management - the source of information. The architecture of the system of identification of semantic, technological and information states of the control object is offered.

Keywords: distributed computer systems; data types; network station; three-level network computer control system; between component interactions; semantic, technological, informational state of the source of information. 